\title{
A fotografia autoral como tradução de memórias e afecções subjetivas em diálogos compartilhados nas ações educativas no espaço cultural
}

\author{
Authorial photography as a translation \\ of memories and subjective affections \\ in shared dialogues in educational \\ activities in the cultural space
}

Ana Paula Sabiá ${ }^{1}$

\footnotetext{
Artista visual, fotógrafa e pesquisadora. Doutora em Artes Visuais pela Universidade do Estado de Santa Catarina (UDESC), na linha de pesquisa Processos Artísticos Contemporâneos. Mestra em Psicologia Social pela Universidade Federal de Santa Catarina (UFSC). Licenciada em Educação Artística com habilitação em Artes Plásticas, pela Fundação Armando Álvares Penteado (FAAP|SP). Membro do grupo de pesquisa Articulações Poéticas (CNPq/UDESC) e do Núcleo de Estudos em Fotografia e Arte (NEFA). Possui experiência profissional no ensino fundamental e médio na área de Artes Visuais e Fotografia. Participa ativamente da cena artística brasileira em exposições, mostras e festivais de fotografia, incluindo seleções, convites e premiações. Atualmente, desenvolve pesquisas a partir do corpo, surrealismo e auto-representação como estratégia de problematização crítica de temáticas que perpassam feminismos, identidades e auto-biografia. Portfólio visual disponivel em: http://www.anasabia.com e @anasabia.as Lattes: http://lattes.cnpq.br/0031308428259339

E-mail: anasabia.as@gmail.com
} 


\title{
Resumo
}

O presente ensaio apresenta parte da série fotográfica autoral intitulada "Do porão ao sótão" na qual busco traduzir e criar em imagens, memórias e devaneios poéticos a partir de referências na literatura de Clarice Lispector e Gaston Bachelard. Exploro a relação entre a casa e o corpo como simbolismos, subjetividades e coletividades a partir de justaposições que tramam arte, psicanálise e fenomenologia. A série, em questão, foi exposta em 2019 à públicos variados, de modo que as ações educativas propostas no espaço cultural também foram diversas. Para visibilizar alguns daqueles diálogos fotográficos, selecionei um grupo específico de idosas e idosos que visitaram a exposição e relataram suas memórias e afecções.

\section{Palavras-chave}

Fotografia autoral; memória; objetos de afeto; casa-corpo; ação educativa.

\begin{abstract}
This essay presents part of the authorial photographic series entitled "From the basement to the attic" in which I seek to translate and create poetic daydreams and memories from references in the literature of Clarice Lispector and Gaston Bachelard. I explore the relationship between the house and the body as symbolisms, subjectivities and collectivities based on juxtapositions that weave art, psychoanalysis and phenomenology. The series in question was exposed in 2019 to various audiences, so that the educational actions proposed in that cultural space were also diverse. To show some photographic dialogues, I selected a specific group of elderly women and men who visited the exhibition and reported their memories and affections.
\end{abstract}

\section{Keywords}

Authorial photography; memory; objects of affection; house-body; education-al action.

ISSN: 2447-1267 


\section{Fotografia e literatura: a criação da imagem como tradução de ser e estar no mundo ${ }^{1}$}

Que a literatura é manancial infindável para a imaginação não é novidade. A tradução e complexidade dos perceptos e afectos por meio da linguagem escrita é oferta para criação em todas as artes. Através da literatura nos é dada a oportunidade de exercitar, entre outras coisas, a faculdade da imaginação e assim tornamo-nos cocriadores nos hiatos e nuances da estória escrita.

Clarice Lispector desde muito tornou-se uma das minhas grandes referências. Pelos tantos retornos à sua literatura em contextos temporais variados, percebo que tanto o entendimento quanto o aprofundamento dela se transforma cada vez que retorno à sua obra e a compreendo sob aspectos anteriormente não tocados.

Em 2010, fui introduzida ao conto 'Amor', do livro "Laços de Família" (1960), através da adaptação para a peça teatral "Ana-me", da Cia. Teatro de Senhoritas. Estava na primeira fila da platéia do pequeno teatro com a responsabilidade de fotografar a apresentação e, apesar da atenção dividida com o ato técnico, aquela peça me emocionou pois me reconheci como aquela Ana, uma das tantas personagens vitais de Lispector.

Alguns anos mais tarde, dessa vez como leitora, a experiência do conto chegou diferente daquela teatral. A começar pelo nome da personagem, igual ao meu, e toda a sequência da história, sua atuação dentro daquele núcleo familiar, sua origem e escolhas, seu contexto e afirmações, tudo ali me levava a identificar-me naquele mundo enfadonho, burguês e cego no qual Ana-personagem vivia.

A Ana de Clarice é uma dona de casa casada, mãe de dois filhos, acomodada, implacável ao manter, cotidianamente, a ordem de seu lar inalterada para evitar acasos inesperados, num certo dia se depara na rua com um cego mascando chicletes. A simples visão de um homem cego que masca um chiclete abre uma fissura no enovelado psicológico da personagem onde, finalmente emerge, a consciência da negação de profundos desejos e frustrações; o evidente transtorno na tarefa de limpar e ordenar os objetos; a manipulação de uma tal realidade fictícia que exclui a própria vida e suas inerentes mazelas e injustiças. A ruptura psíquica, através da visão, se complementa com aquela física: os ovos que Ana carregava dentro da cesta de crochê, que ela mesma tricotara, se rompem com a queda da cesta. Todos a olham, alguns riem, logo tudo volta à normalidade, menos Ana, agora mais viva do que jamais se percebera.

Algo muito perturbador nessa identificação era tão evidente que decidi iniciar uma série fotográfica guiada artisticamente na tradução daquela revolta. Compreendo a literatura clariceana totalmente corporal, sangue, suor, leite, fluidos, nervos, tato corpo matérico - inseparável do intenso embate entre ideias, pensamentos e sensações

\footnotetext{
1 Parte introdutória deste ensaio foi retirado da minha tese de doutorado intitulada "Eu e as Outras: corpo e surrealismo como articulações políticas na obra de mulheres fotógrafas", desenvolvida entre 2015-2019, no Programa de Pós Graduação em Artes Visuais da Universidade do Estado de Santa Catarina (UDESC) sob orientação da Profa. Dr ${ }^{a}$.Marta Lucia Pereira Martins.
} 
em complexa subjetividade. Suas personagens não transcendem, elas são e estão em sua humanidade carnal no aqui e agora da vida concreta e efêmera.

Intitulada como o conto, a fotografia "Amor I" (Fig.1) foi a proposta de tradução dessa anterior passagem que considero o clímax do conto. Ana se rompera tal qual os frágeis ovos. Ou finalmente nascera para a vida fora da casca. Sua rede de proteção artesanalmente tecida não fora tanto eficiente para protegê-los do choque. O inesperado caos que Ana tanto buscava conter e empurrar para longe das horas, veio pela visão do cego: contraste da escuridão e da luz, da brutalidade e ternura, dos acordos e da violência, da mesquinhez e do amor.

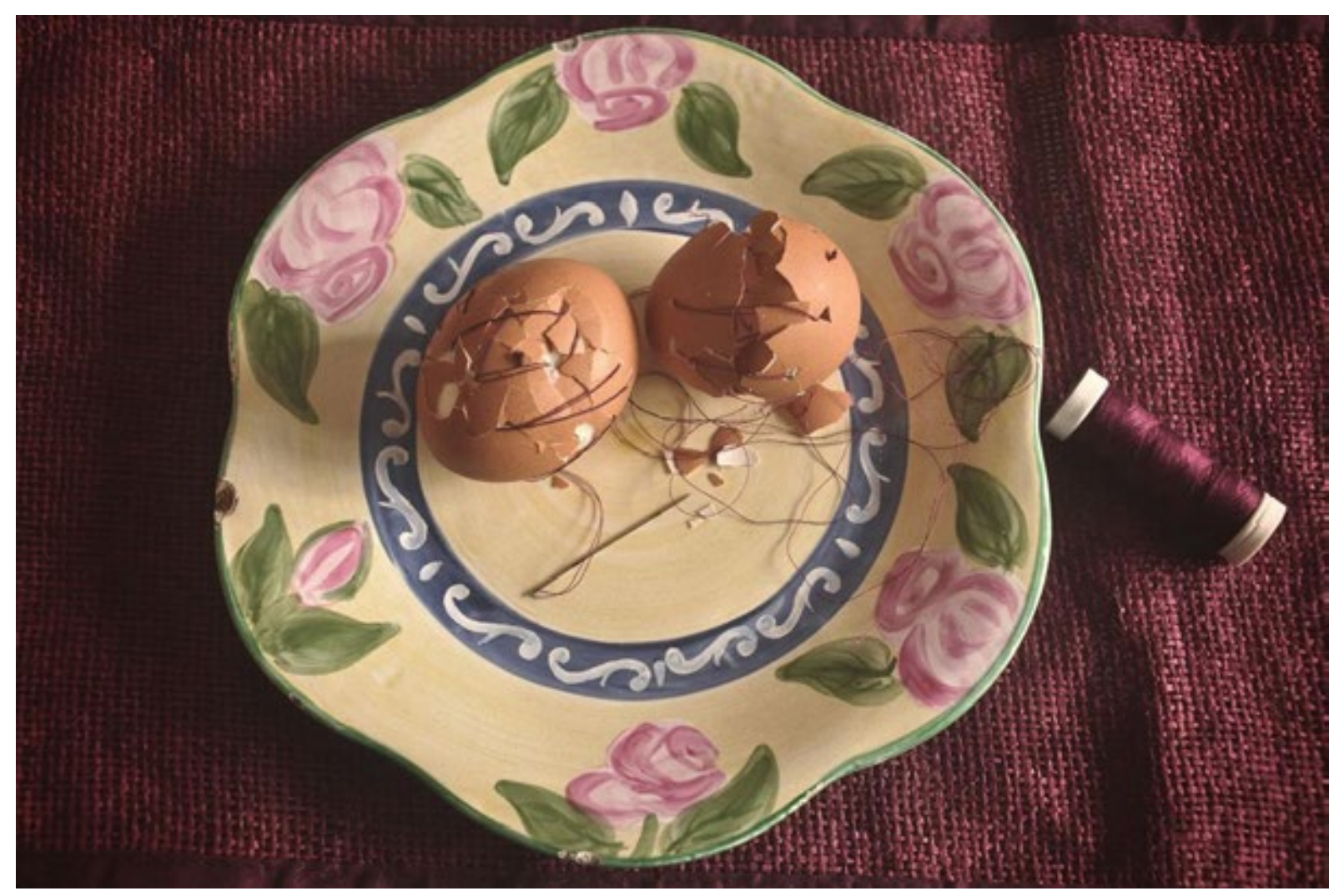

Fig.1. Ana Sabiá. Amor, I (da série 'Do porão ao sótão'). Fotografia digital, 2016.

Na fotografia, o frágil mundo-ovo que partiu-se não retrocederá à superfície lisa e hermética; assim como a vida que ali se aninhava não pode - nunca mais - retornar ao ovo-útero. A sutura é uma evidente tentativa fracassada de reatar estilhaços. Ovos apresentam sua superfície interditada tanto fora quanto dentro: o dentro, quando vivo, só vem para fora quando encontra em condições maduras para tal; o fora só entra, premeditada e imprevistamente, quando o invólucro é rompido. Em ambos os casos, impossível ser o que antes era. A costura tenta remendar e quanto mais se busca atar, mais a lisura se torna esburacada. O restauro torna-se gambiarra.

Por sua natureza inédita, a ação de costurar os ovos envolveu uma pesquisa em seu processo. Primeiro quebrei um dos ovos e com certa dificuldade e delicadeza - para abrir os orifícios a partir da agulha fina - ia alinhavando as cascas vazias. Ao término do cerzir as cascas desencaixadas imitavam o formato de um ovo em desengonçado e 
precário equilíbrio. O segundo ovo, que foi cozido na esperança de manter o formato íntegro e facilitar a penetração da agulha com buracos mais uniformes, apresentou outros entraves com a casca que ia se soltando em pequenos triângulos irregulares e dificultando manter o padrão da emenda.

Costurar os ovos tornara-se uma performance. Conjuga uma ação com teor surreal e divertido ao perceber-me percebendo isso. Foi instigante imaginar a curiosidade de alguém ao presenciar essa ação se desenvolvendo. Mas eu estava só e não a registrei durante o processo. Só a realizei com verdade para mim mesma.

Terminada as emendas arrumei os elementos para compô-los na fotografia. Cada um ali está por um propósito: o tecido cor de vinho com largas tramas, tal qual um crochê, que cobre a mesa é da mesma cor da linha que costura os ovos. O prato que contém os ovos é artesanal pintado à mão. Apresenta flores com traços e cores delicadas aludindo à suposta feminilidade. A linha que costura os ovos ainda continua atada ao carretel e à agulha num emaranhado sobre o prato. E os ovos - a quantidade é fundamental - são apenas dois. Provoca pensar o dualismo do mundo e seus extremos, os duplos e suas diferenças, os casais e seus desencontros, o outro como reflexo de si.

Considerei a fotografia "Amor I" um autorretrato, tanto que compreendi que a partir das demais fotografias da série os elementos trabalhavam o conceito de autorepresentação a partir da transfiguração do corpo como outros elementos, orgânicos e inorgânicos, junto à ideia de ruptura e suas consequências, em narrativas que se reafirmavam nas composições subsequentes.

Entre a fotografia de retrato e autorretrato vou alinhavando documentação e ficção que, afinal de contas, são as faces duais de toda história. O interesse foi discutir uma coletividade a partir de uma privacidade doméstica: a casa, os objetos, as pessoas que ali habitam, suas singularidades percebidas nessa estrutura. Os acontecimentos banais que permeiam a vida e sua finitude são fontes de inesgotável beleza e gravidade se aptos à percebê-los. O microcosmo doméstico carrega a complexidade macro a partir das relações, percepções e posicionamentos ali inscritos.

Neste contexto, essa série problematiza o habitat doméstico, a casa-corpo, e busca evidenciar as armadilhas, conscientes ou não, que permeiam nossas crenças e desejos de voltar no tempo ao constatar nossos equívocos, finitudes e chances de vida desperdiçadas. A ruptura do objeto espelha e dialoga com as rupturas íntimas de desejos, sonhos e ilusões. Os cacos podem ser tanto amontoados cortantes quanto possibilidades vindouras para novos encaixes.

\section{A casa como corpo e o corpo como casa: do porão ao sótão}

Posteriormente intitulada "Do porão ao sótão", a série fotográfica fora realizada, majoritariamente, no interior da minha casa e por considerar, artisticamente, a afirmação deste trabalho na relação entre casa e corpo, o livro "A poética do espaço" do filósofo Gaston Bachelard figura-se como importante referência no diálogo com as imagens. 
Bachelard busca, a partir da perspectiva fenomenológica, encontrar traduções e correspondências entre literatura e imagens onde o espaço privado da casa, o primeiro cosmos de qualquer pessoa, é analisado poeticamente:

[...] todo espaço realmente habitado traz a essência da noção de casa.[...] Por conseguinte, todos os abrigos, todos os refúgios, todos os aposentos têm valores oníricos consoantes. [...] A casa, como o fogo, como a água, nos permitirá evocar na sequencia de nossa obra, luzes fugidias do devaneio que iluminam a síntese do imemorial com a lembrança. Nessa região longínqua, memória e imaginação não se deixam dissociar. Ambas trabalham para o seu aprofundamento mútuo. Ambas constituem, na ordem dos valores, uma união da lembrança com a imagem. Assim, a casa não vive só no dia a dia, no curso de uma história, na narrativa de nossa história. Pelos sonhos, as diversas moradas da nossa vida se interpenetram e guardam os tesouros dos dias antigos. (BACHELARD, Gaston. 1993, p. 25)

O corpo-casa e a casa-corpo são elementos relacionais caros, tanto na psicanálise quanto na arte como, por exemplo, nos trabalhos de Cildo Meirelles, Tunga, Adriana Varejão, Méret Oppenheim, Beth Moysés e Lygia Clark, só para citar alguns nomes. O corpo performa dentro e fora das imagens e se duplica entre corpo e objeto, assim como na Performance Art e na fotografia:

A imagem da "casa", re-significada na obra de arte, reflete sobre o "corpo individual" dentro do "corpo social": essa é uma reflexão de corpo em sua totalidade. O espaço da moradia representado tanto pelos aspectos arquiteturais internos e externos, quanto pelo mobiliário e objetos cotidianos, perpassa, além do conceito de "abrigo" ou, de "espaço privado", a idéia de um "espaço coletivo" primordial. A casa é o ambiente em que se processam os primeiros sentimentos de coletividade; o lugar onde se estruturam modelos de sociedade baseados na organização familiar. Assim, a casa constitui o espaço fundamental das experiências socializantes, e como tal estabelece uma metáfora poderosa do "corpo coletivo" ou, do "corpo social" - uma simbologia que se faz muito presente na arte contemporânea (VIEIRA, Dione Veiga, 2008, s/p).

À essa poética do corpo, tão seminal na arte moderna e tão visceral a partir do final dos anos 1960, com as novas práticas performáticas e o contexto de emancipação das mulheres, o prolongamento do corpo individual se desdobra conceitualmente em outras referencias coletivas que ampliam o significado da obra.

Em 1968, Lygia Clark (1920-1988) apresentou no Brasil e na Itália sua obra "A Casa é o Corpo", instalação de grande importância na história da arte brasileira, que se constituía de uma espécie de abrigo plástico com duas entradas laterais para ser penetrada pelo público. No centro desse espaço-ninho, um labirinto. Lygia propõe com essa obra a reconstrução da experiência intra-uterina, um re-alojar essa casaventre da qual todos/as um dia já habitamos, o compartilhar desse corpo coletivo a partir de tomada de consciência, de emancipação criativa e resistência política através 
da experiência artística².

Muitas das fotografias que compõem essa série continuam a interrogar e relacionar o corpo e os espaços da casa, ainda que a partir de elementos simbólicos. Em "Amor II" (Fig.2), fotografia constituída de montagem fotográfica que apresenta a mesma flor duplicada pela qual evidencio sua morte e uma possibilidade, ainda que irônica, de que esta possa ser reanimada ou ancorada com prendedores de madeira: humildes de sua matéria inerte, eles próprios pedaços de corpos mortos daquela que algum dia foi a íntegra árvore viva. A flor à esquerda já murcha sem viço, suas folhas pendem cansadas, suas flores perderam os tons. A mesma flor é colocada à direita desta vez toda contida e atada por artifícios externos que intentam fazê-la voltar a ser o que um dia foi. Similar aos artifícios cirúrgicos que esticam a pele flácida na promessa de driblar os sinais do tempo no corpo, que continuamente envelhece, na expectativa de distanciar nossa proximidade com a morte.

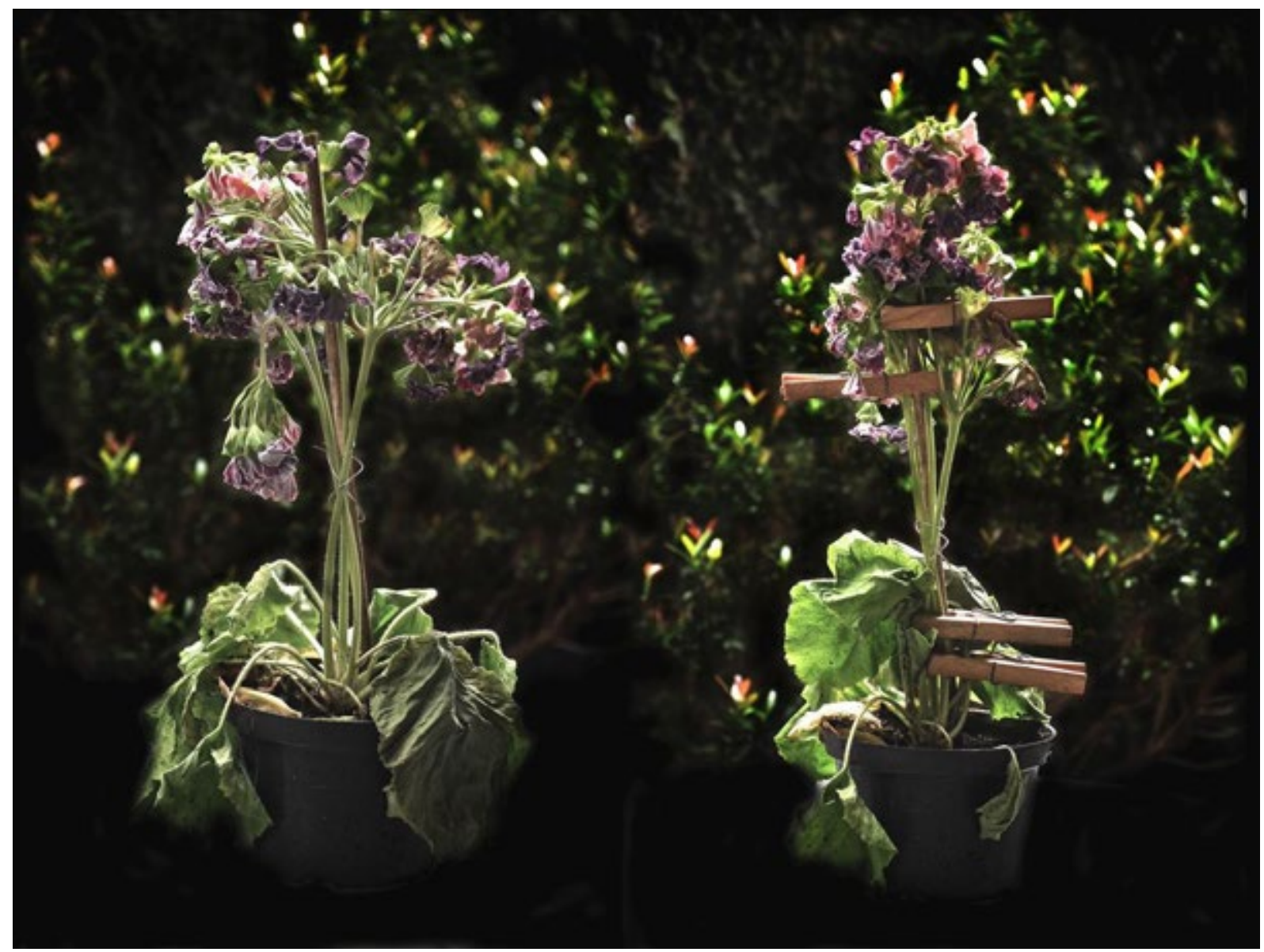

Fig.2. Ana Sabiá. Amor, II (da série 'Do porão ao sótão'). Fotografia digital, 2016.

Em "Amor III", o par delicado de xícaras de porcelana quebradas reconstituemse em precária remenda através da grosseira atadura feita pela fita preta isolante. Aqui, a dupla delicada deixa de ser objeto utilitário como receptáculos aos líquidos, e transborda sentidos outros. 
Os fragmentos pontiagudos e cortantes agora se remontam na esperança da unidade perdida intentando renovar a forma de outrora. Contudo, os inevitáveis veios foram abertos em frestas tortuosas e visíveis a olho nu. O reparo tosco é convenientemente gritante e invasivo, notam-se as pequenas lascas esquecidas apoiando-se desalojadas do todo. A suposta unidade original é um conjunto de dois diferentes e no colapso da fragmentação, agora evidente e sem disfarces, o quebracabeça perde as peças que os fazia perceberem-se enquanto unos. Os orifícios demarcam presença e os líquidos, na impossibilidade de recolherem-se no espaço de contenção, esvaem-se até a última gota.

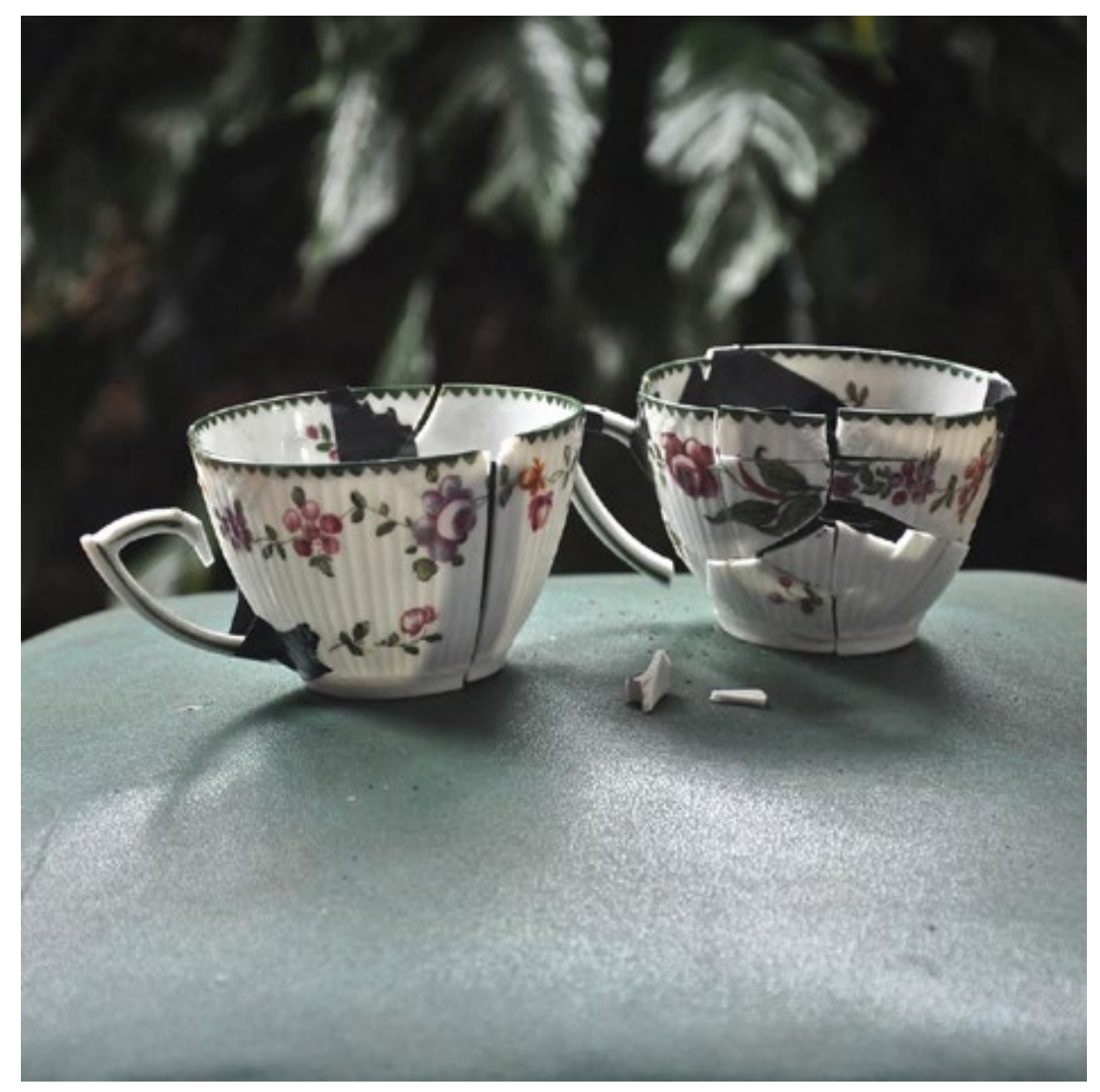

Fig.3. Ana Sabiá. Amor, III (da série 'Do porão ao sótão'). Fotografia digital, 2017.

Em "Amor IV" (Fig.4), um sorridente casal de porcelana se abraça com olhares de intimidade e sarcasmo. A esposa permanece abraçada ao corpo do marido sem cabeça. Esta se encontra decapitada ao lado do corpo, ainda sorridente mas fatalmente fraturada. Um buraco negro se expõe em sua face oca. Trincos partem da fenda escura esquadrinhando todo o rosto.

O uso de louças antigas como auto-representação na minha fotografia está ligada à questões de memória e afeto com os objetos, seus usos e simbologias. Muitas dessas louças são heranças de minha mãe, avós e tias queridas. As reuniões familiares se fazem memoráveis pelo alimento, pelo cuidado e amor ao preparo dos 
melhores sabores compartilhados nas mesas dos lares. $\mathrm{O}$ alimento que nutre o corpo físico mas também fortifica memórias, afeto e subjetividade. $O$ pão que se reparte, do ensinamento cristão, à semente que se planta em terra fértil cresce e multiplica-se na bonança da partilha. O corpo é a ferramenta, a ação e a experiência humanas ao imemorial do tempo.

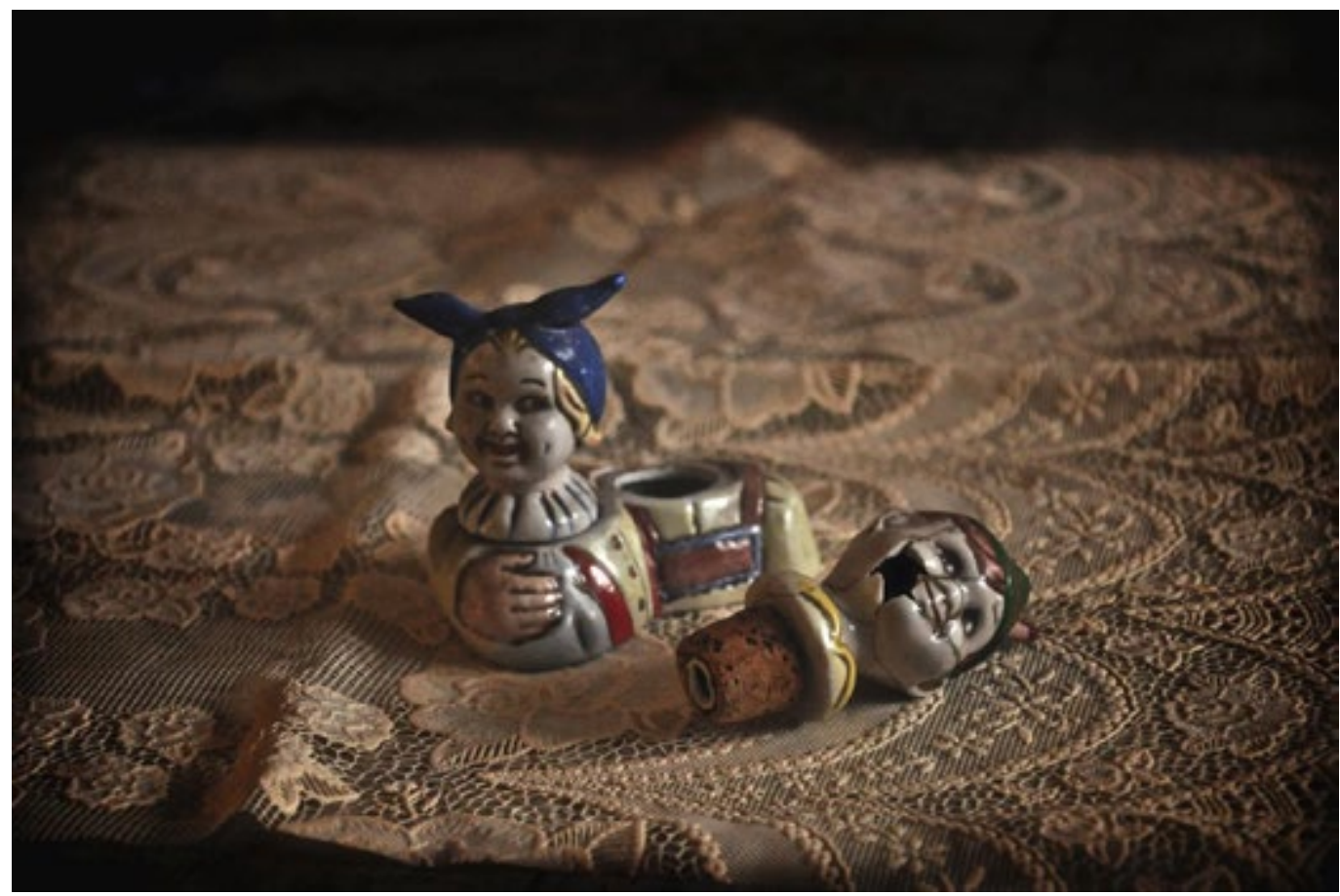

Fig.4. Ana Sabiá. Amor IV, (da série 'Do porão ao sótão'). Fotografia digital, 2017.

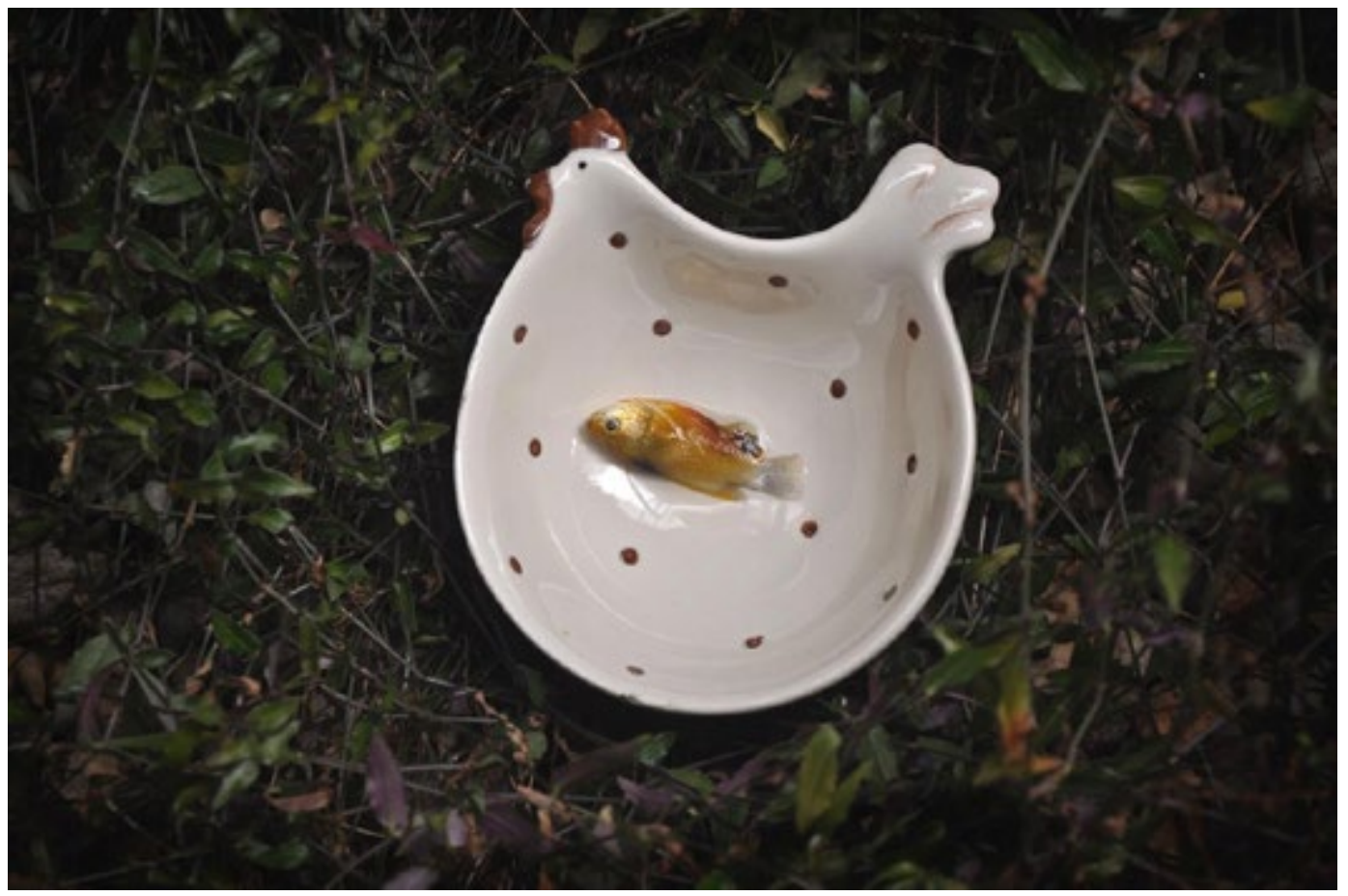

Fig.5. Ana Sabiá. Amor V, (da série 'Do porão ao sótão'). Fotografia digital, 2017. 
Na fotografia "Amor V" (Fig.5) me transmuto, simbolicamente, em uma espécie de ninho inorgânico, sou objeto utilitário e decorativo que ainda que feito de cerâmica aconchego em meu "ventre" um peixinho dourado apenas morto. A assunção dos contrastes entre polos extremos e opostos como morte/vida, orgânico/inorgânico, sujeito/ objeto, masculino/feminino, intimo/público, etc... são essenciais na minha poética fotográfica e na abordagem do corpo e da auto-representação.

De mesmo modo, os objetos que escolho fotografar transformam-se em possibilidades da imaginação ao aferir subjetividade e carne à sua matéria inorgânica, em escalas devalores e importâncias que tangem do individual ao coletivo considerando que comungam de um sistema compartilhado de mercadorias industrializadas;

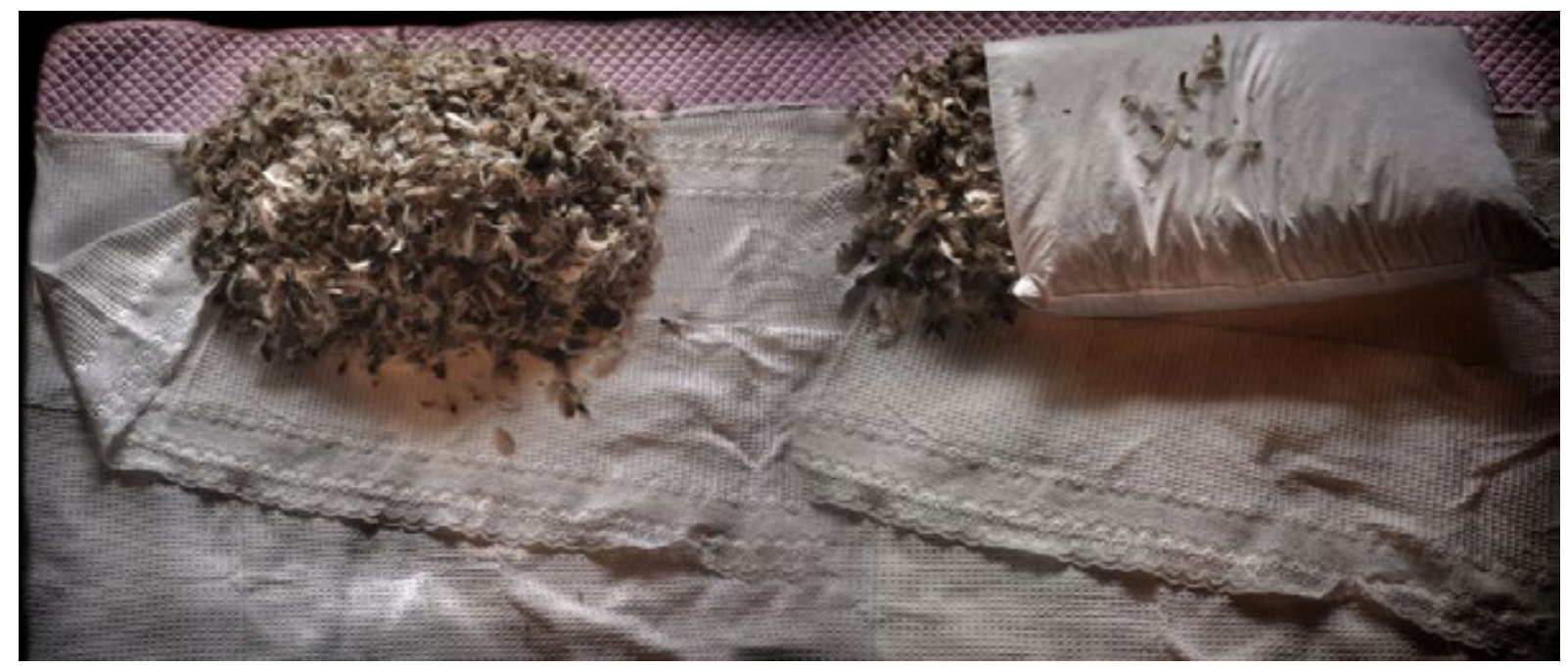

Fig.6. Ana Sabiá. Estado de latência II, (da série 'Do porão ao sótão'). Fotografia digital, 2017.

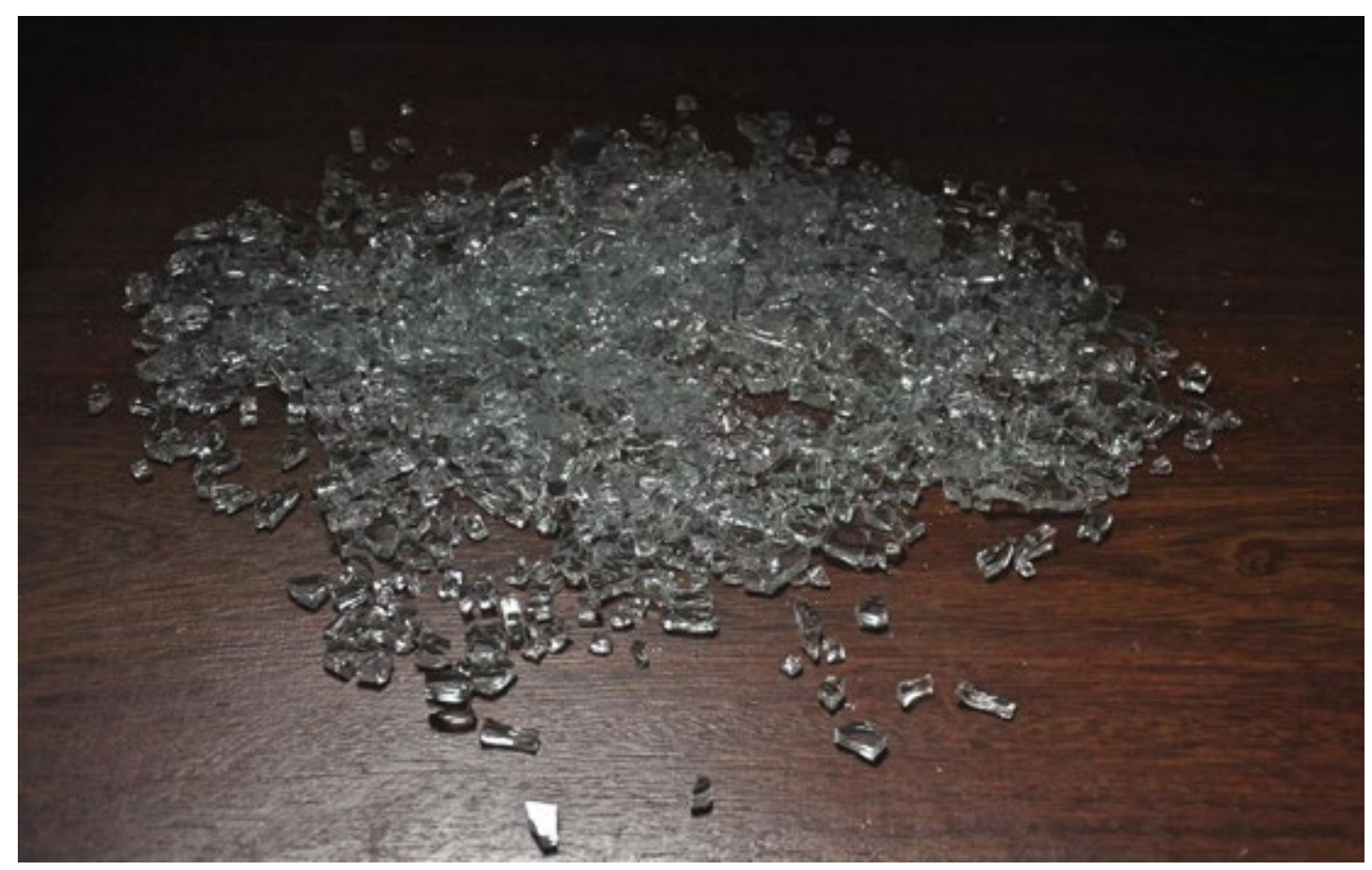

Fig.7. Ana Sabiá. Lágrimas de diamantes, (da série 'Do porão ao sótão'). Fotografia digital, 2017. 
Para um estudo fenomenológico dos valores de intimidade do espaço interior, a casa é, evidentemente, um ser privilegiado; isso, é claro, desde que a consideremos ao mesmo tempo em sua unidade e em sua complexidade, tentando integrar todos os seus valores particulares num valor fundamental. A casa nos fornecerá simultaneamente imagens dispersas e um corpo de imagens. Em ambos os casos, provaremos que a imaginação aumenta os valores da realidade. (BACHELARD, Gaston. 1993, p. 23)

Travesseiros, como corpos (Fig.6), expõem suas vísceras que são feitas de penas, matéria orgânica de outros corpos. "Lágrimas de diamantes" (Fig.7) é o título da fotografia que apresenta um amontoado de vidro translúcido cortante e estilhaçado que seduz na chance de oferecer suavidade de nuvem ao toque mas, se assim o fizermos, possivelmente causará ferimentos.

Corpo, carne, ossos, sangue, leite, gozo, lágrimas e demais matérias palpáveis se corporificam e encarnecem os objetos de afeto, os objetos simbólicos e os objetos ordinários na tentativa poética de amalgamar a vida na arte e a arte na vida para remontar o documentário surreal de um passado, compreender o agora e semear para além.

\section{Memórias em imagens: ações educativas no espaço cultural}

\footnotetext{
"Da exposição fica a lembrança de um passado que não tem volta. O que foi, evolui, se transforma. A infância, a adolescência e mesmo a velhice. Tudo na natureza tem inicio, meio e fim e nós somos parte dela. Não há volta, somente transformação. As cidades se modificam, o que foram nossas casas agora são prédios sem porões onde ideias na infância eram criadas e vividas. O que fica são as lembranças, fotos e gurizadas que (...) nos transportam a um passado inexistente." (escrita de visitante anônima/o na atividade de mediação do 'Grupo da Memória', na exposição "Do porão ao Sótão" na galeria do SESC Joinville, novembro 2019)
}

fazer artístico é incompleto se faltar a oportunidade do encontro entre obra e público. Para a/o artista é uma felicidade se além do encontro acontece o diálogo; quando despertamos os afectos e reflexões para além dos nossos próprios. Considero que é aí que a arte vive e se atualiza, pois ao encontrar com o olhar do outro/a, sua impressões e percepções recriam e complementam a obra em interpretações múltiplas e subjetivas que alargam visibilidades e panoramas gerando um constante caleidoscópio de rearranjos.

A fotografia suscita, por sua própria especificidade imagética, a compreensão de proximidade ao assunto enquadrado que inaugura uma espécie de comunhão entre quem olha e o que alí se vê; uma tal interpretação de concretude que fortalece 
a ideia de realidade e conjuga das inquietações humanas, como defende Bachelard;

Dizer que a imagem poética foge à causalidade é, sem dúvida, uma declaração grave. Mas as causas alegadas pelo psicólogo e pelo psicanalista jamais podem explicar bem o caráter realmente inesperado da imagem nova, nem tampouco a adesão que ela suscita numa alma alheia ao processo de sua criação. O poeta não me confere o passado de sua imagem, e no entanto, ela se enraíza imediatamente em mim. A comunicabilidade de uma imagem singular é um fato de grande significação ontológica. (BACHELARD, Gaston. 1993, p. 02)

Os conceitos e temáticas abordadas nesta série, que tratam, entre outros, da relação entre a casa e o corpo, a memória, a intimidade e a ressignificação subjetiva das experiências da vida, foram trabalhadas de diferentes maneiras de acordo com a diversidade do público que a visitou.

Em 2018, este trabalho foi selecionado no edital do Projeto Rede Sesc de Galerias para itinerar como exposição individual em duas cidades catarinenses ${ }^{3}$. No contexto dessas exposições, a série foi composta por cento e cinquenta fotografias em pequeno formato 4 nas quais a curadora da exposição, Juliana Crispe e eu, as organizamos em quatro categorias nomeadas "Gavetas", "Ninhos", "Miniaturas" e "Conchas" que as agrupavam, de modo a ver similitudes e diálogos entre umas e outras.

Além da curadoria cuidadosa no intento de mediar olhares na ampliação de afecções, destaco a relevância e compromisso de toda a equipe técnica de cultura do Sesc de Joinville, coordenada por Sandra Checruski e pelo retorno, através da redação de um relatório a mim dirigido, sobre as atividades de mediação com o público visitante da exposição no período em que esteve aberta ${ }^{5}$.

Segundo consta no relatório, o grupo da Educação Infantil vivenciou uma atividade sensorial com objetos que estão presentes nas fotografias da série, os quais foram colocados em uma grande caixa surpresa na qual as crianças

[...] experimentaram e descobriram através do tato as diferentes texturas de objetos como folhas, galhos, plástico bolha e porcelana; saborearam frutas e cheiraram os diversos odores relacionados às fotografias. Houve grande entrega por parte das crianças em vendar os olhos e participar dessa descoberta. (CÁCERES, B.E., CHECRUSKI, S.,2019, p.02).

Para as turmas de Ensino Fundamental do Sesc Escola foram realizadas atividades nas quais os alunos foram incentivados a materializar "suas percepções através do corpo, em um jogo que consistia na criação de uma imagem congelada relacionada

3 São Bento do Sul (agosto/setembro de 2018) e Joinville (entre os dias 11 de outubro e 30 de novembro de 2018).

4 Medidas entre $10 \times 10 \mathrm{~cm}, 10 \times 15 \mathrm{~cm}, 15 \times 15 \mathrm{~cm}$ e $15 \times 21 \mathrm{~cm}$ cada fotografia.

5 Em fevereiro de 2019 recebi por Correios um envelope remetido pelo Serviço Social do Comércio/SESC em Joinville, onde constava um "Relatório da Exposição" de três páginas com minúcias de todas as atividades e mediações junto ao público visitante da exposição, elaborado por Eric Cáceres e Sandra Checruski. 
as obras presentes e criação de uma contação de história coletiva." (ibid)

Em parceria do Sesc/Joinville com o grupo Das Unbewusste - Estudos em Psicanálise, foi realizado o módulo "Um olhar sobre a criação", que integra o Projeto Arte, Cultura e Psicánalise ${ }^{6}$.

Contudo, a atividade de mediação realizada como o Grupo da Memória7 foi aquela que, concretamente, chegou à minha casa. Do SESC, me foi remetido por Correios um envelope contendo um considerável amontoado de cartões-postais onde, na frente consta a reprodução em preto e branco da fotografia "Amor I", e no verso pequenos textos escritos à mão e destinados à 'Querida Ana'.

Cada postal escrito era a síntese pessoal de um sujeito singular a partir de suas impressões e afetos surtidos após conhecer cada fotografia do meu trabalho. E agora, então, acontecia novamente o entrecruzamento de linguagens: a fotografia, outrora referenciada pela literatura, era agora ressignificada e traduzida pela escrita do/a Outro/a.

Aquelas caligrafias individuais, ora vacilantes ora firmes, por vezes infantil ou escrita "de médico", estremecidas ou arredondadas, assinadas ou anônimas, saídas diretamente de suas memórias afetivas, se correspondiam e contavam sua memórias pessoais;

Lembrei dos meus 9 aos 15 anos de idade. Hoje estou com 70 anos. Foi uma época maravilhosa da minha vida. Estudava interna em um colégio em Blumenau neste período. Nas férias ia para Ituporanga onde ficava a minha residência. Assim minha casa tinha um lindo sótão onde eu dormia. Era tudo muito aconchegante. Nos meus 15 anos recebi um linda festa e a maior surpresa foi receber um quarto todo novo e decorado neste lindo sótão. Assim foi uma época muito linda, muito abençoada e gratificante de minha vida. (Visitante anônima/o 1)

Nessa escrita, percebemos a casa como a norteadora das boas e aconchegantes lembranças de um período feliz, um devaneio de acolhimento e fantasia como apresenta Bachelard;

Nessas condições, se nos perguntassem qual o benefício mais precioso da casa, diríamos: a casa abriga o devaneio, a casa protege o sonhador, a casa permite sonhar em paz. Só os pensamentos e as experiências sancionam os valores humanos. Ao devaneio pertencem valores que marcam o homem em sua profundidade. O devaneio tem mesmo um privilégio de autovalorização. Ele usufrui diretamente de seu ser. (BACHELARD, Gaston. 1993, p. 26)

A leitura daquele montante de cartões-postais foi emocionante principalmente

6 "O encontro teve início com a apresentação dos projetos e dos psicanalistas André Luis Cabral e Paula Noquet, momento após o qual o público foi convidado a contemplar as fotografias, o qual foi seguido da leitura do conto de Lispector, como mote para a roda de conversa e intercâmbio com temas de interesse da psica-nálise, como o luto e a angústia, e as possíveis leituras dos convidados e o público externo. A conversa contou com a participação de 14 pessoas, entre público em geral, mediadores e colaboradores do Sesc." (CÁCERES, B.E., CHECRUSKI, S.,2019, p.02)

7 Grupo formado por 55 idosos do Setor de Assistência do Sesc/Joinville. 
por dois motivos. O primeiro, já mencionado, é que mesmo desconhecendo pessoalmente as autoras e autores daquelas cartinhas, conseguimos estabelecer uma comunicação afetiva que se deu por um disparador efetivo: as fotografias. O segundo motivo é o fato destes visitantes idosos, caracterizado como Grupo da Memória, fazer parte de um projeto institucional que fomenta atividades para o lazer, cultura e bem viver que busca ir na contra-mão do esquecimento, do tédio e da solidão que tristemente são infringidos à esse público em nossa sociedade.

Alguns relatos explicitam o fato de que aquela ocasião foi sua primeira visita em uma exposição de arte, "Esta exposição é a primeira que participo. Gostei muito" (visitante anônima/o 2); ou de suas lembranças de quando eram crianças:

Senti saudades dos tempos de criança da mesa dos bilros onde minha nona fazia as rendas do baú onde se guardava as roupas, lembrei da minha infância. (visitante anônima/o 3)

Recordação do passado e da infância. Boas e ruins.(visitante anônima/o 4)

[...] retrata o cotidiano de nossa vida no seu inicio ao ápice. Me vi dentro das cenas que a exposição traz com muita clareza. Vemos que o que morre nem sempre retorna na mesma maneira, sempre tem algo novo surgindo. Os acontecimentos do cotidiano muito se parece a muitas pessoas (...) retornei à minha infância até os dias atuais nas cenas da exposição. (visitante anônima/o 5)

Quando criança tinha boneca de louça me fez voltar ao passado. As florzinhas que a gente soprava e suas pequenas pétalas voavam. Já em outra época mais crescida, banheira de plástico que dava banho nos meus filhos. Outra lembrança, andando de barco no meio do lago o pássaro pousado em um pau que ficava fincado no lago, chamava bastante atenção. (visitante anônima/o 7)

[...] trouxe-me lembranças da infância, como a flor dente-de-leão a tangerina com seu cheiro e uma brincadeira que fazíamos de contar as sementes de cada gomo ou tentar adivinhar. Remeteu ainda quão bela é a natureza representada pelas plantas. Talvez não saberei explicar bem ao certo o que mais me chamou atenção mais com certeza houve um refletir sobre a vida. (visitante anônima/o 6)

\section{Da vida, da morte, do renascimento e da transformação}

Como há muito debatido por teóricos da fotografia, é inerente nosso entusiasmo frente à imagem considerando sua qualidade de transitar entre morte e vida. É uma 
ferramenta de captação da vida em constante fluidez, não obstante sua suspensão no instante que disparamos o obturador da câmera.

Ao ver uma imagem plasmada em fotografia sabemos que o que estivera frente à lente foi uma vida que não se repetirá jamais. Contudo, olhar para esse "rigor mortis" fotográfico é, simultaneamente, trazê-lo à vida pronta à novas oportunidades, sentidos e resignificações, à exemplo de outros relatos de visitantes idosos na exposição:

[...] me impressiona observar as fotos de cacos, nos mostrando que independente de quantos cacos são quebrados, sempre existe a possibilidade de ser reconstruído um dia. (visitante anônima/o 8)

O que mais me impressionou foram as xícaras quebradas, peças faltando pedaços... é assim que acontece com nossos relacionamentos de amor e amizade... quando se partem... não ficam mais iguais, o inteiro fica fica sempre faltando um pedaço. Tudo que é da natureza: arvores e água, mares e rios nos confortam quando estamos tristes e decepcionados. A natureza é generosa. (visitante anônima/o 09)

Generoso e emocionante foi um outro presente que encontrei junto aos cartões postais a mim remetidos pelo Grupo Da Memória: um conjunto de porta copos feito em crochê de um delicadíssimo amarelo antigo, provavelmente saído diretamente de alguma gaveta de afeto de uma das queridas senhoras visitantes ${ }^{8}$.

A trama delicada do crochê, formando uma espécie híbrida entre flores e mandala, é concretude e devaneio. Fantasio as mãos que a teceu, sua notável habilidade técnica, a projeção de seu ideal de criação enquanto tecia e a materializava.

De modo análogo, na criação da série fotográfica "Do porão ao sótão", em cada fotografia e todo elemento ali é como um ponto ou nó na trama da imagem: tem um propósito estético e simbólico, como afirma Bachelard "o devaneio poético, criador de símbolos, dá à nossa intimidade uma atividade polissimbólica" (BACHELARD, Gaston. 1993, p. 25).

Os objetos e espaços de afeto, como a boneca, a banheira de plástico e o quarto de infância, as brincadeiras infantis de outrora, momentos felizes com os filhos pequenos ou o primeiro amor, os elementos singelos ou mesmos aqueles brutais do porão ao sótão - e vice-versa - atravessavam a superfície da minha fotografia para tatear ou perturbar aqueles e aquelas que se colocaram permeáveis ao diálogo.

$\mathrm{Na}$ possibilidade dessa linguagem, proporcionado pela imagem fotográfica, parece ser palpável tecer uma tênue linha que trama, sustenta e re-arranja a própria condição humana: o fazer estético e criativo, as subjetividades, as identidades, as culturas, os devaneios poéticos, as concretudes materiais na intermitente espiral da vida entre o aparecimento, o encontro, a criação e sua extinção.

A linha que conecta eu e a/o outra/o, eu e o mundo, eu e o contexto compartilhado

8 Soube que foi uma senhora quem me presenteou, ainda que seu nome não me foi identificado. Contudo, gostaria de atribuir esse gesto à todas e todos daquele grupo. 
se faz pelo amor e arte ainda que, por vezes, tal costura se faça disforme, dissonante e quase surreal, a exemplo de costurar ovos.

\section{Referências}

BACHELARD, Gaston. A poética do espaço. São Paulo: Martins Fontes, 1993.

BRAUNE, Fernando. O surrealismo e a estética fotográfica. Rio de Janeiro: 7 letras, 2000.

CÁCERES, B. Eric; CHECRUSKI, Sandra. Relatório de exposição elaborado pela equipe técnica de Cultura do SESC Joinville, 2019.

COTTON, Charlotte. A fotografia como arte contemporânea. Trad. Maria Silvia Mourão. São Paulo: Ed. WMF Martins Fontes, 2010.

FRAYZE-PEREIRA, João A. Arte, Dor: inquietudes entre estética e psicanálise. São Paulo. Ateliê Editorial, 2005.

JUNG, Carl Gustave. O homem e seus símbolos. Rio de Janeiro: Nova Fronteira, 2008.

LISPECTOR, Clarice. Laços de Família: contos. Rio de Janeiro: Rocco, 2009.

SABIÁ, Ana Paula. Eu e as Outras: corpo e surrealismo como articulações políticas na obra de mulheres fotógrafas. Tese de doutorado vinculada ao Programa de Pós Graduação em Artes Visuais, Universidade do Estado de Santa Catarina (PPGAV/UDESC), 2019.

VIEIRA, DIONE VEIGA. A projeção do corpo no contexto da obra - uma reflexão a partir da instalação "A casa é o corpo" de Lygia Clark, in <http://sibila.com.br/novos-e-criticos/aprojecao-do-corpo/2269> visitado em outubro de 2018. 